\title{
Correction to: The effect of low dose marine protein hydrolysates on short-term recovery after high intensity performance cycling: a double-blinded crossover study
}

Ingunn Mjøs ${ }^{1,2}$, Einar Thorsen ${ }^{3,4}$, Trygve Hausken ${ }^{5,6}$, Einar Lied ${ }^{7}$, Roy M. Nilsen', Ingeborg Brønstad ${ }^{5,6}$, Elisabeth Edvardsen ${ }^{8,9}$ and Bente Frisk ${ }^{1,2^{*}}$

\section{Correction to: J Int Soc Sports Nutr (2019) 16:48 https://doi.org/10.1186/s12970-019-0318-3}

The original article [1] contains errors in Tables 1 and 3: Table 1 erroneously mentions use of a treadmill which should instead state 'bicycle', and Table 3 has a minor typesetting mistake.

The correct versions of both Tables can be viewed ahead in this Correction article.

\begin{abstract}
Author details
'Department of Health and Functioning, Western Norway University of Applied Sciences, Pb. 7030, 5020 Bergen, Norway. ${ }^{2}$ Department of Physiotherapy, Haukeland University Hospital, Bergen, Norway. ${ }^{3}$ Department of Clinical Science, University of Bergen, Bergen, Norway. ${ }^{4}$ Department of Occupational Medicine, Haukeland University Hospital, Bergen, Norway. ${ }^{5}$ Department of Clinical Medicine, University of Bergen, Bergen, Norway. ${ }^{6}$ National Centre for Ultrasound in Gastroenterology, Haukeland University Hospital, Bergen, Norway. ${ }^{7}$ Firmenich Bjørge Biomarin A/S, Aalesund, Norway. ${ }^{8}$ Department of Pulmonary Medicine, Oslo University Hospital, Ullevål, Oslo, Norway. ${ }^{9}$ Norwegian School of Sport Sciences, Oslo, Norway.
\end{abstract}

Published online: 03 January 2020

\section{Reference}

1. Miøs I, Thorsen E, Hausken T, Lied E, Nilsen RM, Brønstad I, et al. The effect of low dose marine protein hydrolysates on short-term recovery after high intensity performance cycling: a double-blinded crossover study. J Int Soc Sports Nutr. 2019;16:48. https://doi.org/10.1186/s12970-019-0318-3.

The original article can be found online at https://doi.org/10.1186/s12970019-0318-3

* Correspondence: bente.frisk@hvl.no

'Department of Health and Functioning, Western Norway University of Applied Sciences, Pb. 7030, 5020 Bergen, Norway

2Department of Physiotherapy, Haukeland University Hospital, Bergen,

Norway

Full list of author information is available at the end of the article

(c) The Author(s). 2019 Open Access This article is distributed under the terms of the Creative Commons Attribution 4.0 International License (http://creativecommons.org/licenses/by/4.0/), which permits unrestricted use, distribution, and reproduction in any medium, provided you give appropriate credit to the original author(s) and the source, provide a link to the Creative Commons license, and indicate if changes were made. The Creative Commons Public Domain Dedication waiver (http://creativecommons.org/publicdomain/zero/1.0/) applies to the data made available in this article, unless otherwise stated. 
Table 1 Baseline characteristics of the participants and physiological responses to the incremental exercise test on bicycle

\begin{tabular}{|c|c|}
\hline Characteristics $(N=14)$ & Mean \\
\hline Age (years) & $45.6 \pm 5.3$ \\
\hline Height (cm) & $181 \pm 4$ \\
\hline Weight (kg) & $80.1 \pm 6.4$ \\
\hline BMI $\left(\mathrm{kg} / \mathrm{m}^{2}\right)$ & $24.5 \pm 2.2$ \\
\hline Muscle mass (kg) & $37.7 \pm 2.3$ \\
\hline Fat mass (\%) & $16.6 \pm 4.4$ \\
\hline$\dot{\mathrm{V}} \mathrm{O}_{2 \max }\left(\mathrm{ml} \cdot \mathrm{min}^{-1} \cdot \mathrm{kg}^{-1}\right)$ & $54.7 \pm 4.1$ \\
\hline Workload $_{\max }$ (Watt) & $422 \pm 32$ \\
\hline $\mathrm{RER}_{\max }$ & $1.20 \pm 0.10$ \\
\hline$\dot{V}_{\text {Emax }}(L / \min )$ & $167 \pm 16$ \\
\hline Lactate $_{\max }(\mathrm{mmol} / \mathrm{L})$ & $11.2 \pm 1.4$ \\
\hline $\mathrm{HR}_{\max }(\mathrm{bpm})$ & $185 \pm 8$ \\
\hline Glucose $_{\max }(\mathrm{mmol} / \mathrm{L})$ & $4.8 \pm 1.1$ \\
\hline Borg $\mathrm{RPE}_{\max }$ (median) & 19 \\
\hline
\end{tabular}

Data are presented as mean \pm standard deviation (SD) unless otherwise stated. BMI: body mass index; $\dot{V}_{2 \text { max }}$ maximal oxygen uptake; RER: respiratory exchange ratio; $\dot{\mathrm{V}}_{\mathrm{E}}$ : ventilation; $\mathrm{HR}$ : heart rate; RPE: rating of perceived exertion

Table 3 Differences between morning minus afternoon cycling sessions for CHO-WP-MPH and CHO-WP and comparison of the diets

\begin{tabular}{|c|c|c|c|c|c|}
\hline & \multirow{2}{*}{$\begin{array}{l}{ }^{\mathrm{a}} \mathrm{CHO}-\mathrm{WP}-\mathrm{MPH} \\
\mathrm{N}=14 \\
\text { Mean diff } \pm \mathrm{SD}\end{array}$} & \multirow{2}{*}{$\begin{array}{l}{ }^{\mathrm{a}} \mathrm{CHO}-\mathrm{WP} \\
\mathrm{N}=14 \\
\text { Mean diff } \pm \mathrm{SD}\end{array}$} & \multicolumn{3}{|c|}{ Diff. CHO-WP-MPH versus CHO-WP } \\
\hline & & & Mean diff & $95 \% \mathrm{Cl}$ & $p$-value \\
\hline${ }^{{ }^{\mathrm{b}} T_{i m e}}{ }_{\text {diff }}$ at $95 \%$ of $\dot{\mathrm{V}}_{2 \max }(\mathrm{min})$ & $1.37 \pm 2.03$ & $0.52 \pm 1.17$ & 0.85 & $-0.37,2.06$ & 0.156 \\
\hline $\mathrm{HR}(\mathrm{bpm})$ & $-0.9 \pm 2.4$ & $-1.7 \pm 3.0$ & 0.8 & $-0.9,2.5$ & 0.331 \\
\hline RER & $-0.01 \pm 0.03$ & $-0.06 \pm 0.21$ & -0.05 & $-0.07,0.17$ & 0.361 \\
\hline Lactate $(\mathrm{mmol} / \mathrm{L})$ & $1.88 \pm 0.83$ & $2.12 \pm 1.02$ & -0.24 & $-1.00,0.53$ & 0.511 \\
\hline Glucose (mmol/L) & $0.78 \pm 0.65$ & $0.55 \pm 0.73$ & 0.23 & $-0.05,0.51$ & 0.094 \\
\hline
\end{tabular}

Data are presented as mean values, standard deviations (SD), 95\% confidence interval (Cl), and $P$-value. Diff. CHO-WP-MPH versus CHO-WP: differences between morning and afternoon cycling sessions with ingestion of CHO-WP-MPH versus CHO-WP. ${ }^{a}$ Five participants ingested CHO-WP-MPH and nine CHO-WP in the first intervention (phase II) and in the second intervention (phase III) nine participants ingested $\mathrm{CHO}-\mathrm{WP}-\mathrm{MPH}$ and five CHO-WP. ${ }^{\mathrm{b}} \mathrm{Time}_{\text {diff }}$ at $95 \%$ of $\dot{\mathrm{VO}}_{2 \max }$ : differences between cycling time in the morning and in the afternoon at $95 \%$ of $\dot{\mathrm{VO}}_{2 \text { max. }} \mathrm{CHO}$, carbohydrate; $\mathrm{WP}$, whey protein; $\mathrm{MPH}$, marine protein hydrolysate; diff, difference; HR, Heart rate; bpm, beats pr. min; RER, respiratory exchange ratio 